\title{
GROBNA CJELINA 40 S RANOSREDNJOVJEKOVNOG GROBLJA ZVONIMIROVO - VELIKO POLJE
}

\begin{abstract}
U radu se tematizira važnost nalaza grobne cjeline 40 otkrivene 2004. godine unutar ranosrednjovjekovnoga groblja bjelobrdskog obilježja na položaju Veliko polje pokraj sela Zvonimirovo u Općini Suhopolje. Analizom grobnoga inventara autor nastoji prepoznati vremenski okvir ukopa pokojnice opremljene bogatim ukrasima oglavlja i odjeće. Na temelju srodnih usporednih nalaza u međuriječju Mure, Drave, Dunava i Save te u prekodravskom dijelu Karpatske kotline nastoje se prepoznati sociološke karakteristike pokojnice, tj. status unutar rodovske zajednice, odnosno razina njezinih umjetničko-obrtnih dosega i kulturnih doticaja. Grobni inventar predstavlja vrlo značajnu teseru u složenom i osebujnom mozaiku bjelobrdskog kulturnog kruga.

Ključne riječi: groblje Zvonimirovo - Veliko polje; nakit oglavlja; ukrasi odjeće; rodovska zajednica; pokopavanje na redove; rani srednji vijek; bjelobrdski kulturni krug; Hrvatska.
\end{abstract}

\section{Uvodne napomene}

Arheološko nalazište kraj sela Zvonimirova na položaju Veliko polje, u podravskom dijelu Slavonije, znanstvenim je krugovima poznato na temelju otkrića dvaju groblja koja se preklapaju na koti 113, tj. na povišenoj glinenoj gredi prekrivenoj eolskim pijeskom, južno od prastarog meandra rijeke Drave (karta 1). 


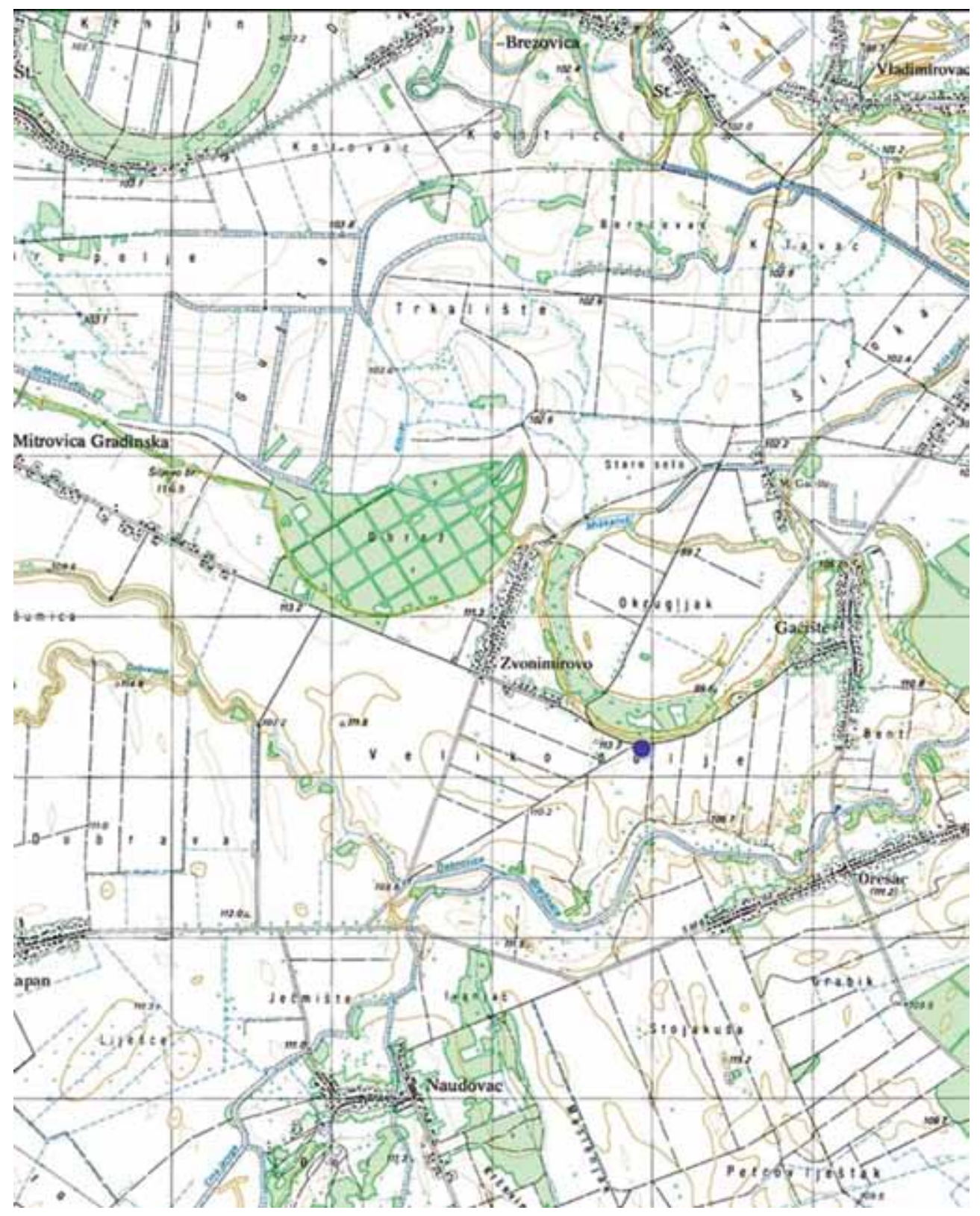

Karta 1. Položaj groblja Zvonimirovo - Veliko polje (mj. 1: 25.000). 
Riječ je o ranosrednjovjekovnom rodovskom groblju s obilježjima bjelobrdskog kulturnog kruga, tj. s tjelesnim pokapanjem pokojnika položenih, potpuno odjevenih, $\mathrm{u}$ grobne rake raspoređene $\mathrm{u}$ redove, te o groblju latenske kulture iz mlađeg željeznog doba sa spaljivanjem pokojnika. O istraživanjima groblja na položaju Veliko polje objavljena je opsežna literatura. ${ }^{1} \mathrm{U}$ iskopavanjima je istražena površina od oko $2.900 \mathrm{~m}^{2}$ na kojoj je u razdoblju 1993. - 2016. godine pronađeno 115 paljevinskih grobova latenske kulture i 42 groba koja pripadaju ranosrednjovjekovnom rodovskom groblju na redove. Osim grobnih nalaza otkrivenih u pouzdanom arheološkom kontekstu na položaju groblja na Velikom polju, tijekom pokusnih istraživanja prikupljeni su i brojni pojedinačni nalazi iz uništenih grobnih cjelina obaju vremenskih horizonata pokapanja. Uništavanje grobnih cjelina obaju kulturnih horizonata rezultat je kontinuiranih poljodjelskih radova na Velikom polju. Valja napomenuti da su na sjevernom dijelu uzvisine groblja zabilježeni i keramički nalazi koji pripadaju razdoblju kasnoga srednjeg vijeka, pa vjerojatno upućuju na postojanje istodobnog sela. Naselja stanovnika koji su se u doba latenske i bjelobrdske kulture pokopavali na Velikom polju pokusno su istražena 1998. godine, a nalazila su se na rubu nekadašnje dravske terase u sjeveroistočnom dijelu sela Zvonimirovo (Sekelj Ivančan, Belaj 1998: 112-117). Valja napomenuti da je tijekom antičkog razdoblja tim područjem pokraj aglomeracije Bolentium (Orešac) prolazila prometnica preko riječnog prijelaza na Dravi prema koloniji Sopianae (Pečuh). Bio je to sjeverni odvojak poznate antičke ceste od kolonije Poetovio (Ptuj) prema koloniji Mursa (Osijek).

Kao što je već ranije navedeno, tijekom dosadašnjih istraživanja u razdoblju 1993. - 2004. godine na položaju ranosrednjovjekovnog groblja Zvonimirovo Veliko polje, otkrivene su sveukupno 42 grobne cjeline (karta 2). Na situacijskom planu groblja razabire se osam relativno pravilnih redova ukopanih pokojnika, položenih u plitke grobne rake s orijentacijom pokojnika od zapada prema isto$\mathrm{ku}$, tj. s pogledima prema izlasku sunca. Redovi grobova pružaju se od jugoza-

Ovdje donosimo kratak izbor radova: Tomičić, Željko. 1994. Istraživanja srednjovjekovnoga groblja Zvonimirovo-Veliko polje u Virovitičko-podravskoj županiji, Obavijesti HAD-a XXVI/2, Zagreb, 6164. Tomičić 1994: 61-64; Tomičić, Željko. 1997. Zvonimirovo i Josipovo groblja starohrvatskoga doba u Virovitičko- podravskoj županiji Zagreb-Virovitica; Tomičić, Željko 1999, Ranosrednjovjekovno groblje Zvonimirovo-Veliko polje. Prinos poznavanju bjelobrdske kulture u podravskom dijelu Slavonije, Prilozi Instituta za arheologiju vol. 13-14 (1996.1997.), Zagreb, 91-120; Tomičić, Željko. 2004. Rezultati istraživanja na Velikom polju kraj sela Zvonimirova tijekom godine 2004., Obavijesti - Hrvatsko arheološko društvo XXXVI/3, Zagreb, 122-126. 122-126; Tomičić, Ž.- Dizdar, M. 2005: 59-125; Tomičić, Ž. 2012, ZVONIMIROVO Veliko polje. Groblje bjelobrdske kulture, Katalog, Zagreb; Dizdar, Marko. 2005. Groblje latenske kulture u Zvonimirovu - prilog poznavanju pogrebnih običaja i vjerovanja Tauriska u Podravini, Histria Antiqua 13, Pula, 85-98; Dizdar, M. 2013, Zvonimirovo Veliko polje. Groblje latenske kulture (A Cemetery of the La Tène Culture) 1, Monografije Instituta za arheologiju 8, Zagreb. 
pada prema sjeveroistoku. U grobnim cjelinama pokapane su žene, muškarci i djeca, što je dokaz da je riječ o uobičajenom rodovskom groblju s pokapanjem pokojnika na redove. Pokojnice su bile pokapane s bogatim grobnim inventarom, poglavito ukrasima oglavlja (raznolikim inačicama naušnica i karičica), ogrlicama od poludragulja (ametista i fluorita), staklenih perli i kauri pužića, potom s raznolikim prstenjem, odnosno ukrasima odjeće (dvodijelnim srcolikim privjescima i praporcima) $\mathrm{i}$ jednim primjerkom novca, $\mathrm{t}$. srebrnim denarom kralja Ladislava I. (1077. - 1095.). Pokapanje je obavljano tijekom barem dvaju naraštaja u razdoblju od prve trećine 10 . do konca 11. stoljeća.

\section{Grobna cjelina 40}

U samoj biti pojave ukopa doista je sadržan koncept vremenske kapsule. Naime, za arheologa je najinformativniji spoj individualnog kostura pokojnika koji je u grobnu raku bio položen potpuno odjeven i popraćen grobnim prilozima - izborom osobnih predmeta ili darova koje je prenosio u zagrobni život - što može imati presudnu važnost pri određivanju spola, društvenog statusa i duhovnog opredjeljenja, ali ujedno pomaže i pri datiranju (Green 1995: 88). To je bio povod što smo pozornost usmjerili prema vrednovanju grobne cjeline 40, koja je otkrivena 18. svibnja 2004. u sjeveroistočnom dijelu groblja na Velikom polju pokraj sela Zvonimirova u Općini Suhopolje (karta 2). Svakako treba naglasiti da je grobna cjelina 40 otkrivena u blizini nekolicine najbogatije opremljenih grobnih cjelina pokopanih žena, koje raznolikim inventarom odaju dojam istaknutijih članica, odnosno mogli bismo pretpostaviti, odličnica unutar više društvene razine dijela ruralne zajednice (rodovske aristokracije). Ta je ruralna poljodjelska populacija živjela u spomenutom ranosrednjovjekovnom selu u relativnoj blizini groblja. 


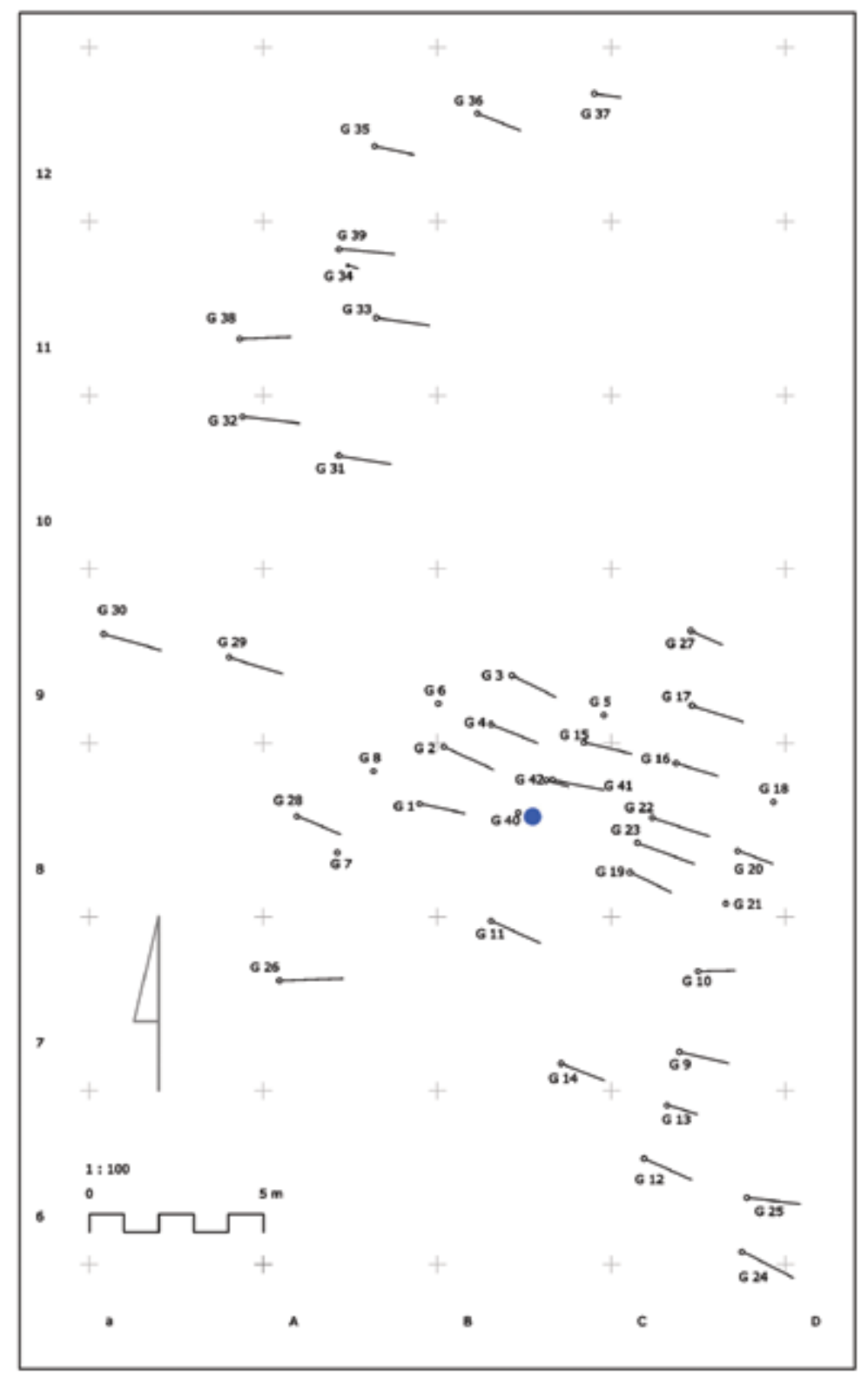

Karta 2. Situacijski plan ranosrednjovjekovnog groblja Zvonimirovo - Veliko polje s položajem grobne cjeline 40. (crtež Kristina Turkalj) 


\section{Opis grobne cjeline}

Loše uščuvan kostur, položen u raku pravokutna oblika zaobljenih uglova u kvadrantu B-8. Vrh rake nalazio se na dubini od 113,58 m, dok je dno bilo na $113,51 \mathrm{~m}$. Duljina rake iznosila je 1,24 m, dok je najveća širina rake bila $0,45 \mathrm{~m}$. Kostur je bio položen u ispruženom položaju na leđima. Uslijed oranja dosta je oštećena glava, kosti lijeve podlaktice te kosti šaka, stopala i zdjelice. Uščuvana desna ruka blago je savijena u laktu i položena u zdjelicu. Duljina kostura iznosila je 1,00 m. Kostur je bio položen u smjeru Z-I s otklonom od $106^{\circ}$ od sjevera. Spol: žena; dob: ?. Vrlo vjerojatno djevojčica. Pokretni nalazi pohranjeni su u Gradskom muzeju u Virovitici.

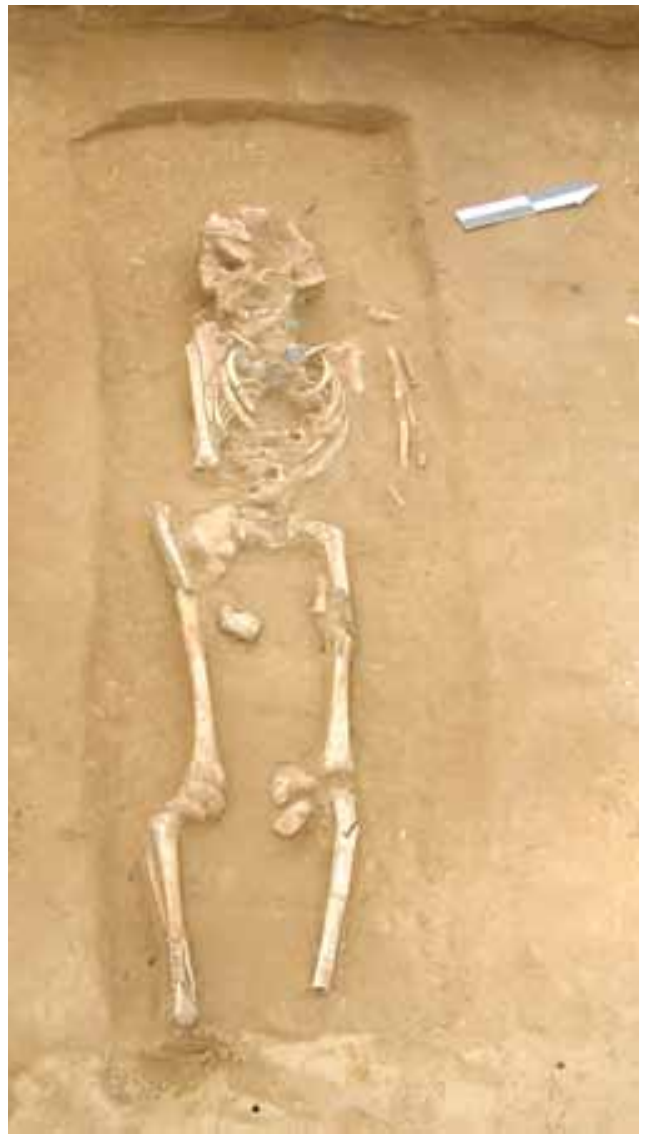

SI. 1. Zvonimirovo - Veliko polje. Grobna cjelina 40. (snimio Hrvoje Jambrek)

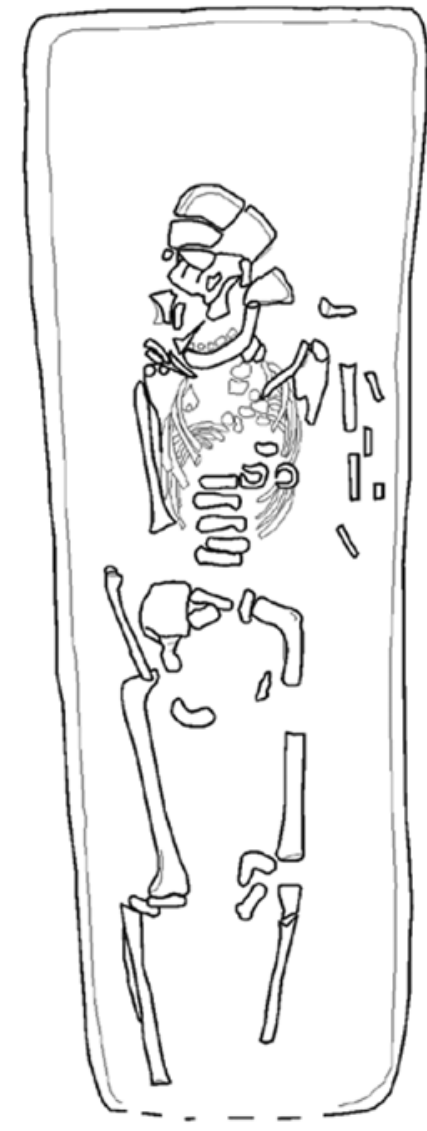

SI. 2. Zvonimirovo -Veliko polje. Grobna cjelina 40. (crtež Daria Ložnjak Dizdar, digitalizacija Kristina Jelinčić Vučković) 


\section{Raspored i vrste grobnog inventara}

Lijevo od kostiju glave pronađena je lijevana grozdasta naušnica s četiri koljenca tipa G.17b (1). ${ }^{2}$ Ispod glave, s desne strane, pronađeno je još pet lijevanih grozdastih naušnica s četiri koljenca tipa G.17b (2-6). S lijeve strane glave, ispod glave te na prsima pokojnice pronađeni su ostaci ogrlice od dvodijelnih srcolikih privjesaka tipa G.9a, odnosno tipa T.42a, brončanih praporaca tipa G.10 te perli od puhanog stakla nanizanih na tkaninu tipa G.39-40 (7). Lijevo od glave pronađena su dva srcolika privjeska tipa G.9a, odnosno tipa T.42a (7a, b). Na prsima pokojnice pronađena su još tri dvodijelna srcolika privjeska od srebra i brončanog gornjeg dijela tipa G.9a, odnosno tipa T.42a (7c-e). Oko prsa je pronađeno nekoliko sitnih perlica (7k) te dva dvodijelna srcolika privjeska tipa G.9a, odnosno T.42a $(7 \mathrm{~g}, \mathrm{~h})$ kao i niz perli nanizanih na tkaninu (7k) s kojima su bili povezani praporac tipa G.10 (7j) te srcoliki dvodijelni privjesak tipa G.9a, odnosno tipa T.42a (7f). Pokretni su nalazi nakon prepariranja i konzerviranja u Hrvatskom restauratorskom zavodu pohranjeni u Gradskom muzeju u Virovitici.

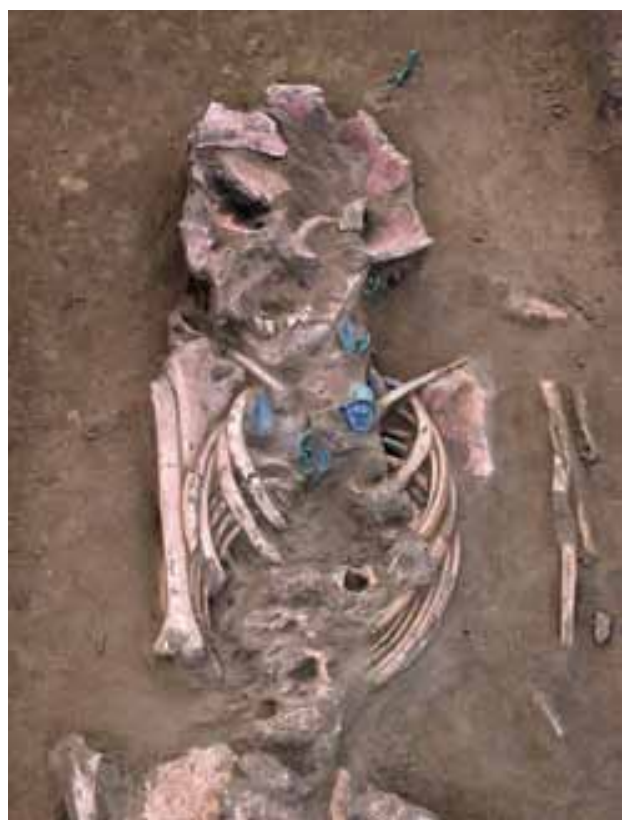

SI. 3. Zvonimirovo - Veliko polje. Nalazi dvodijelnih srcolikih privjesaka. Stanje tijekom istraživanja. (snimio Marko Dizdar)

$\overline{2} \quad$ Za tipološke oznake nakita koje je 1981. godine predložio Jochen Giesler koristimo kraticu G (npr. tipa G.17b), za tipološke oznake dvodijelnih privjesaka koje je 1983. predložio Željko Demo koristimo kraticu D (npr. tipa D.10), a za tipološke oznake autora ovog priloga predložene 1989. godine koristimo kraticu T (npr. tipa T.42a). 


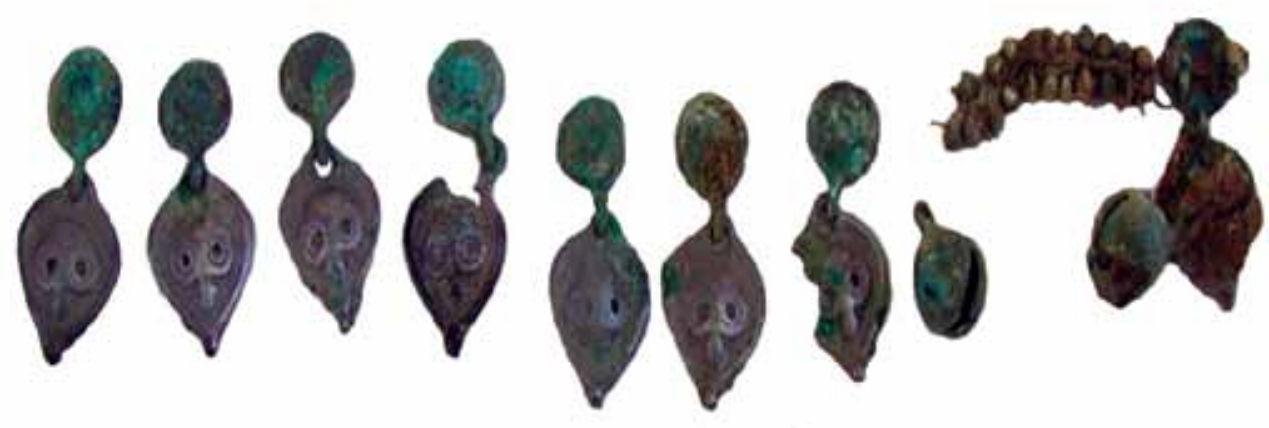

SI. 4. Zvonimirovo - Veliko polje. Ogrlica od dvodijelnih srcolikih privjesaka, praporaca, perli od puhanog stakla i tkanine. Stanje tijekom istraživanja. (snimila Daria Ložnjak Dizdar)

\section{Ukrasi oglavlja}

1. Naušnica; srebro. Lijevana inačica grozdaste naušnice s četirima koljencima - tip G.17b. Duljina: 4,2 cm; promjer karike: 2,6 cm; debljina karike: 0,15 $\mathrm{cm}$; duljina lijevanog dijela: $3 \mathrm{~cm}$; širina lijevanog dijela: 0,6 cm. (PN 832)

2. Naušnica; srebro. Lijevana inačica grozdaste naušnice s četirima koljencima - tip G.17b. Karika je slomljena u dva dijela. Duljina: 5,1 cm; promjer karike: 2,9 cm; debljina karike: 0,15 cm; duljina lijevanog dijela: 2,9 cm; širina lijevanog dijela: 0,7 cm. (PN 839)

3. Naušnica; srebro. Lijevana inačica grozdaste naušnice s četirima koljencima - tip G.17b. Duljina: 4,1 cm; promjer karike: 2,6 cm; debljina karike: 0,15 $\mathrm{cm}$; duljina lijevanog dijela: 2,9 cm; širina lijevanog dijela: 0,65 cm. (PN 840)

4. Naušnica; srebro. Lijevana inačica grozdaste naušnice s četirima koljencima - tip G.17b. Duljina: 4,7 cm; promjer karike: 2,7 cm; debljina karike: 0,15 $\mathrm{cm}$; duljina lijevanog dijela: $3 \mathrm{~cm}$; širina lijevanog dijela: $0,7 \mathrm{~cm}$. (PN 841)

5. Naušnica; srebro. Lijevana inačica grozdaste naušnice s četirima koljencima - tip G.17b. Duljina: 4,6 cm; promjer karike: $3 \mathrm{~cm}$; debljina karike: 0,16 cm; duljina lijevanog dijela: $2,9 \mathrm{~cm}$; širina lijevanog dijela: 0,7 cm. (PN 842)

6. Naušnica; srebro. Lijevana inačica grozdaste naušnice s četirima koljencima - tip G.17b. Karika je slomljena u dva dijela. Na lijevanom dijelu naušnice vidljivi su ostatci tkanine. Duljina: 4,3 cm; promjer karike: $3,1 \mathrm{~cm}$; debljina karike: 0,15 cm; duljina lijevanog dijela: 3,1 cm; širina lijevanog dijela: 0,6 cm. (PN 843) 

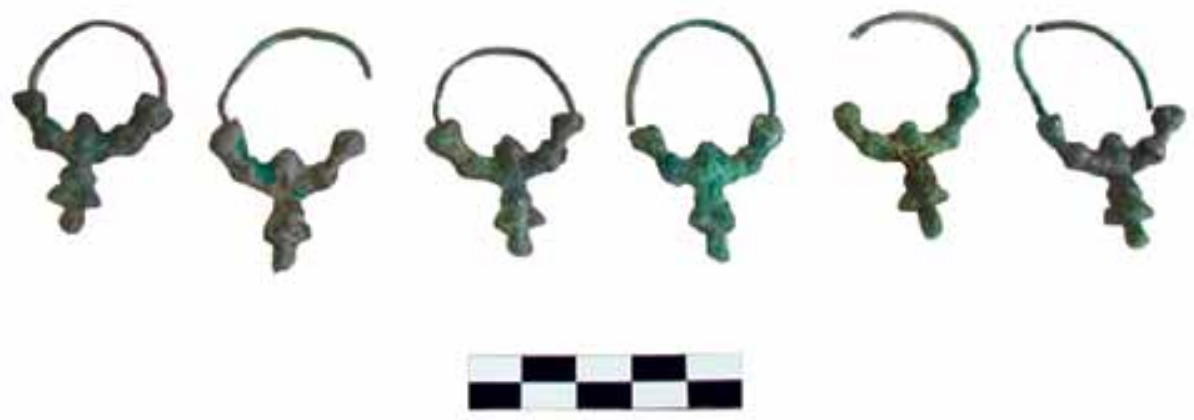

SI. 5. Grobna cjelina 40. Srebrne lijevane rustikalne grozdaste naušnice s četirima koljencima. Stanje prije konzerviranja. (snimio Jurica Škudar)

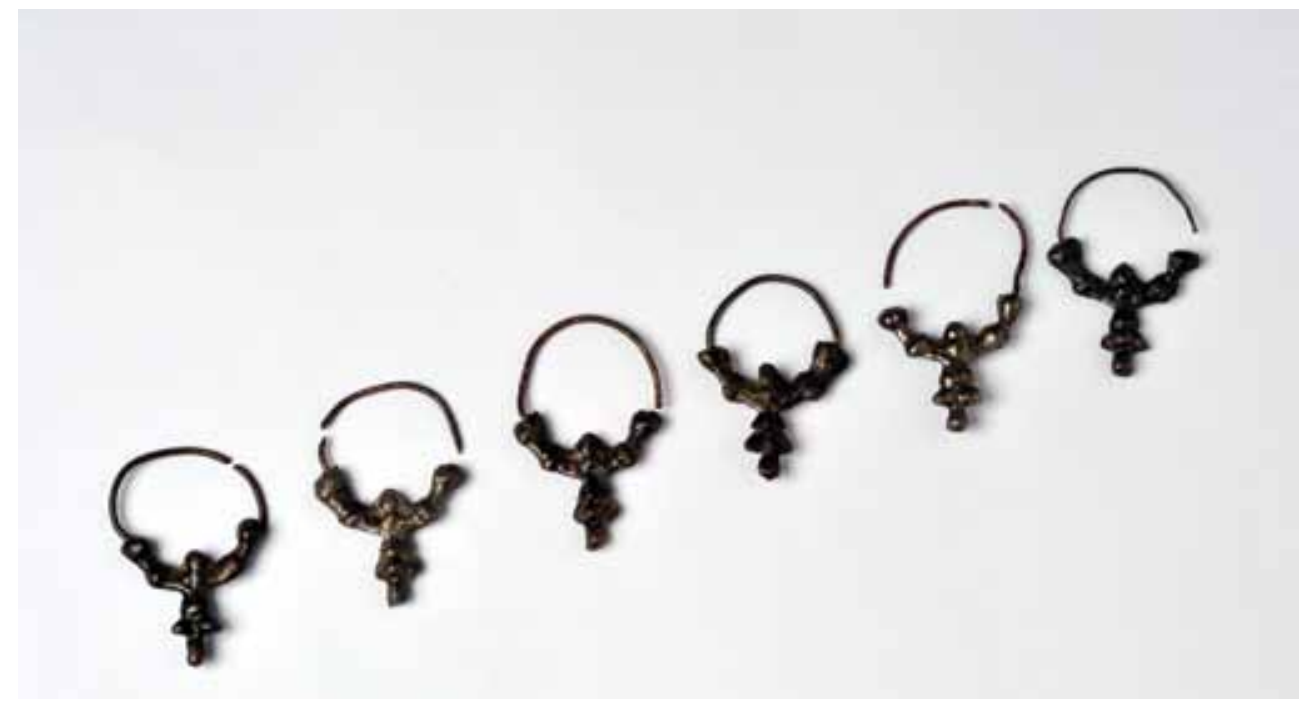

SI. 6. Grobna cjelina 40. Srebrne lijevane rustikalne grozdaste naušnice s četirima koljencima. Stanje nakon konzerviranja. (snimio Hrvoje Jambrek) 


\section{UKRAS ODJEĆE}

\section{Ogrlica}

7. Ogrlica (niska) koja je sastavljena od 8 dvodijelnih srcolikih privjesaka tipa D.10, tipa T.42a, 2 praporca tipa G.10 i 116 perli tipa G.39 i tipa G.40, nanizanih na niti tkanine.

a) Privjesak; srebro, bronca. Dvodijelni srcoliki privjesak - tipa D.10. Duljina: $4,4 \mathrm{~cm}$; promjer gornjeg dijela: $1,5 \mathrm{~cm}$; duljina donjeg dijela: $2,6 \mathrm{~cm}$; širina donjeg dijela: 2,1 cm. (PN 833)

b) Privjesak; srebro, bronca. Dvodijelni srcoliki privjesak - tipa D.10. Duljina: 4,3 cm; promjer gornjeg dijela: $1,5 \mathrm{~cm}$; duljina donjeg dijela: $2,7 \mathrm{~cm}$; širina donjeg dijela: $2 \mathrm{~cm}$. (PN 834)

c) Privjesak; srebro, bronca. Dvodijelni srcoliki privjesak - tipa D.10. Kroz ušice na gornjem dijelu provučene su niti tkanine. Nedostaje gornji dio donjeg srcolikog dijela privjeska. Duljina: 4,2 cm; promjer gornjeg dijela: 1,55 cm; duljina donjeg dijela: $2,5 \mathrm{~cm}$; širina donjeg dijela: $2 \mathrm{~cm}$. (PN 835)

d) Privjesak; srebro, bronca. Dvodijelni srcoliki privjesak - tipa D.10. Slomljena je karika gornjeg okruglog dijela privjeska. Duljina: $4,4 \mathrm{~cm}$; promjer gornjeg dijela: 1,5 cm; duljina donjeg dijela: $2,8 \mathrm{~cm}$; širina donjeg dijela: $2,1 \mathrm{~cm}$. (PN 836)

e) Privjesak; srebro, bronca. Dvodijelni srcoliki privjesak - tipa D.10. Kroz ušice na gornjem dijelu provučene su niti tkanine. Duljina: $4,2 \mathrm{~cm}$; promjer gornjeg dijela: $1,5 \mathrm{~cm}$; duljina donjeg dijela: $2,7 \mathrm{~cm}$; širina donjeg dijela: $2,1 \mathrm{~cm}$. (PN 837)

f) Privjesak; srebro, bronca. Dvodijelni srcoliki privjesak - tipa D.10. Na gornjem okruglom dijelu privjeska nalaze se ostaci tkanine. Duljina: $4,4 \mathrm{~cm}$; promjer gornjeg dijela: $1,5 \mathrm{~cm}$; duljina donjeg dijela: $2,7 \mathrm{~cm}$; širina donjeg dijela: 2,1 cm. (PN 848)

g) Privjesak; srebro, bronca. Dvodijelni srcoliki privjesak - tipa D.10. Donji srcoliki dio privjeska oštećen je s jedne strane. Duljina: $4,4 \mathrm{~cm}$; promjer gornjeg dijela: $1,5 \mathrm{~cm}$; duljina donjeg dijela: $2,7 \mathrm{~cm}$; sačuvana širina donjeg dijela: 1,9 cm. (PN 849)

h) Privjesak; srebro, bronca. Dvodijelni srcoliki privjesak - tipa D.10. Kroz ušice na gornjem dijelu provučene su niti tkanine s perlama - tip G.39. Na stražnjoj strani donjeg srcolikog dijela privjeska nalaze se ostatci tkanine. Duljina: 4,3 $\mathrm{cm}$; promjer gornjeg dijela: $1,5 \mathrm{~cm}$; duljina donjeg dijela: $2,7 \mathrm{~cm}$; sačuvana širina donjeg dijela: $2,1 \mathrm{~cm}$. (PN 851) 
i) Praporac; bronca. Praporac - tipa G.10.a. Duljina: 2,1 cm; promjer: 1,7 cm; promjer ušice: $0,45 \mathrm{~cm}$. (PN 847)

j) Praporac; bronca. Praporac - tipa G.10.a. Na ušici praporca nalaze se ostatci tkanine na koju je praporac bio pričvršćen. Duljina: 2,3 cm; promjer: 1,6 cm; promjer ušice: $0,6 \mathrm{~cm}$. (PN 852)

k) Perle; puhano staklo. Perli od puhanog stakla ima nekoliko vrsta: perle od svijetlog puhanog stakla - 58 komada (PN 838, 850, 851); 1. perle od tamnog puhanog stakla - 10 komada (PN 838); 2. perle od zelenog puhanog stakla 40 komada (PN 838); 3. dvodijelna perla od puhanog stakla -8 komada (PN 838). Perle od puhanog stakla označio je Giesler kao tip G. 39-40.

1) Tkanina. Ostatci tkanine na koju je ogrlica bila nanizana. (PN 844)

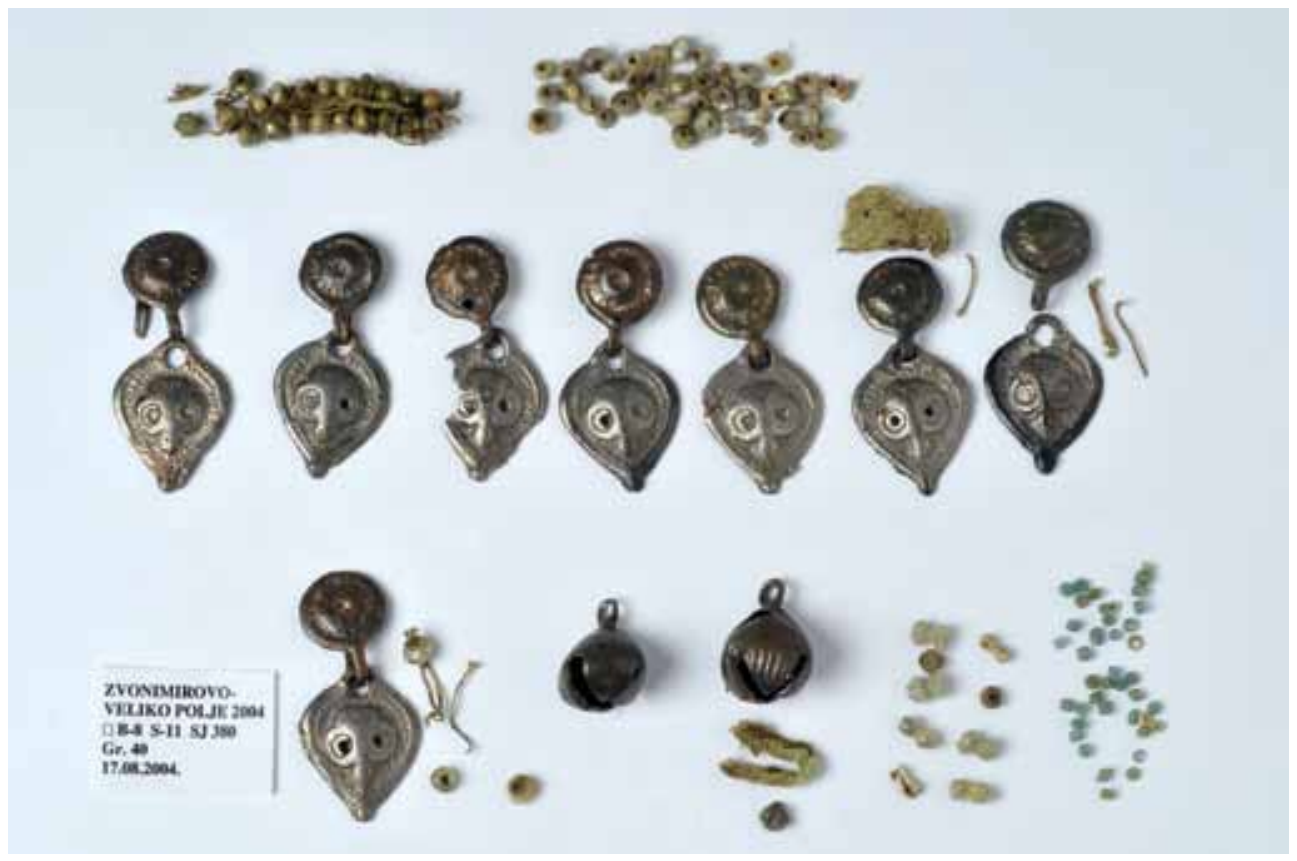

SI. 7. Grobna cjelina 40. Ogrlica od dvodijelnih srcolikih privjesaka, praporaca i staklenih perli nanizanih na tkaninu. (snimio Jurica Škudar) 
Rad Hrvat. akad. znan. i umjet. Razred za druš. znan. 54=539(2019) : 97-123

\section{VREDNOVANJE POKRETNIH NALAZA I USPOREDNE POJAVE}

\section{Lijevane rustikalne grozdaste naušnice s četirima koljencima - tipa G.17b.}

U grobnoj cjelini 40 oko glave pokojnice pronađeno je šest lijevanih srebrnih grozdastih naušnica s četirima koljencima nanizanim vjerojatno na lanenu vrpcu i upletenim u kosu pokojnice. Šest primjeraka rustikalnih lijevanih srebrnih grozdastih naušnica s četirima koljencima predstavljaju u inventaru grobne cjeline 40 vrijedan nalaz kojemu treba posvetiti odgovarajuću pozornost. Taj je ukrasni predmet oglavlja ujedno najčešća, odnosno jedna od najrasprostranjenijih pojava unutar spektra nakita bjelobrdskog kulturnog kruga. Unutar međuriječja Mure, Drave, Dunava i Save te u sjeverozapadnoj Bosni i Hercegovini registrirana su dosad već 24 nalazišta tog osebujnog tipa bjelobrdskog nakita, što, dakako, sugerira njihovu omiljenost unutar ranosrednjovjekovne populacije, kao i postojanje različitih većih ili manjih središta njihove lokalne proizvodnje. Stoga je shvatljivo i pojavljivanje više inačica te vrste nakita. Na njih nailazimo, za sada, samo na tri nalazišta u Kneževini Hrvatskoj (Sokol 2006: 87-88; Petrinec 2009: 234, T. 153,5, T. 260,9 i T. 287,4). Već je ranije Zdenko Vinski primijetio razlike u kakvoći izrade lijevanih naušnica kojima je podario naziv volinijske, s obzirom na njegovo uvjerenje da su im ishodišta bila u pokrajini Voliniji na području Kijevske Rusije (Vinski 1970: 63, bilj. 101). Razlikovao je kvalitetnije i rustikalnije primjerke, uz luksuzne granulirane neposredne importe. Naša analiza postojećeg fundusa uvjerila nas je u postojanje stanovite kakvoće izradbe, koje su odražavale postojanje nekih izdvojenih središta, tj. zlatarskih umjetničko-obrtnih radionica. Te su radionice za lokalne potrebe, ali i za zahtjeve trgovine proizvodile srodne inačice svih vrsta naušnica (Tomičić 1989: 444). Takvo je središte umjetničko-obrtnog stvaralaštva bilo u Sisku, kako je to dokazano kalupom za lijevanje grozdastih naušnica otkrivenim u Sisku (Vinski 1970: 50-51). J. Giesler je 1981. naušnice s grozdastim privjeskom i s četirima koljencima na obruču označio kao tip 17, s dvije inačice (a i b). Luksuzna inačica rađena je u tehnici granulacije (tip G.17a). Lijevane grozdaste rustikalne inačice naušnice s četirima koljencima - tzv. tipa G.17b - registrirane su u međuriječju Drave, Dunava i Save na 19 položaja groblja te u jednom naselju (Velika Gorica Šepkovčica). Granulirane naušnice tipa G.17a Giesler je smjestio u prijelaznu fazu između staromađarskog i bjelobrdskog horizonta kako se to razabire iz njegova tabelarnog prikaza kronološke podjele materijala bjelobrdske kulture u kojem te naušnice zauzimaju vremenski raspon od oko 950. godine do potkraj vladavine ugarskog kralja Stjepana I. Svetog (1000. - 1038.) (Giesler 1981: 91, Taf. 53,2). U pojavi lijevanih grozdastih rustičnih naušnica s četirima koljencima tipa G.17b 
Giesler je prepoznavao mogućnost određenog kronološkog iskaza, pa je u groblju Gomjenica kraj Prijedora pokušao pronaći odgovor kada je došlo do pojave lijevanih grozdastih naušnica s četirima koljencima (Giesler 1981: 102). Giesleru je bilo jasno da se luksuzne granulirane inačice naušnica tipa G.17a pojavljuju u sredini koja poznaje samo lijevane oblike naušnica. Horizontalno-stratigrafska istraživanja u Gomjenici pokazala su da se lijevane rustične grozdaste naušnice s četirima koljencima tipa G.17b prema mišljenju Gieslera pojavljuju u mlađoj fazi korištenja groblja, dakle nakon pojave lijevanih grozdastih naušnica tipa 14, 15 i 16 (Giesler 1981: 102). Istu je situaciju Giesler zatekao i u groblju Halimba-Cseres (grob 70), pa je na tim spoznajama dokazivao da se inačica lijevanih grozdastih naušnica tipa G.17b u inventaru spomenutih groblja pojavljuje nakon pojave ostalih lijevanih oblika naušnica (Giesler 1981: 101). Ujedno je pretpostavio i postojanje jednog razdoblja $\mathrm{u}$ kojem su granulirane i lijevane grozdaste naušnice egzistirale usporedno (Giesler 1981: 103), ali u doba nastanka njegova rada to se još nije moglo dokazati (Tomičić 1989: 433-449). Međutim, tu je pretpostavku moguće potkrijepiti upravo nalazima iz groblja Zvonimirovo - Veliko polje, u što ćemo se uvjeriti kasnije.

U prilog ranoj pojavi naušnica s četirima koljencima (tip G.17) nalazimo potvrde u inventaru grobnih cjelina 11, 18, 19 i 139 u groblju na redove bjelobrdske kulture Bagruša kraj Petoševaca u Bosanskoj Posavini, sjeverno od Banje Luke (Žeravica 1985-1986: 124-196; Tomičić 2010: 117-166). Lijevane rustikalne grozdaste naušnice s četirima koljencima tipa G.17 pojavljuju se ondje u najranijoj fazi pokopavanja (Tomičić 2010: 131-132). Susrećemo ih u grobnim cjelinama broj 11 (Tomičić 2010: Tabla VI, 4,5), 18 (Tomičić 2010: Tabla VIII, 1), 19 (Tomičić 2010: Tabla IX, 2) i 139 (Žeravica 1985-1986: T. II, 5 i 10, T. III, 2 i 4, T. VII, 4-6; Tomičić 2010: Tabla XXIII, 1-4), kako nam to pokazuje njihov položaj unutar situacijskog plana groblja (Tomičić 2010: Tabla I). Valja svakako naglasiti kako se lijevane grozdaste naušnice s četirima koljencima ili Gieslerov tip G.17b u inventaru spomenutih grobnih cjelina na Bagruši pojavljuju u dvije stilski izdvojene i prepoznatljive inačice. Prije svega valja istaknuti iznimno dragocjene nalaze para relativno malenih i kvalitetno vrlo dobro lijevanih naušnica s grozdastim ukrasom trupa i četirima koljencima na krakovima koje susrećemo u kombinaciji s dva para lijevanih grozdastih naušnica s dvama koljencima (tip G.14) u inventarom bogatoj grobnoj cjelini 11 (Žeravica 1985-1986: T. II, 5 i 10; Tomičić 2010: Tabla VI, 4,5). Podjednake, vrlo kvalitetno lijevane grozdaste naušnice s dvama koljencima, izrađene od legure srebra i bronce, pronađene su pojedinačno u grobnim cjelinama broj 18 (Tomičić 2010: Tabla VIII, 1) i 19 (Tomičić 2010: Tabla IX, 2). Premda je Gieslerovo uvjerenje bilo da naušnice tipa G.14 valja datirati oko sredine 10. st., tj. u njegovu ranu fazu I. stupnja bjelo- 
brdske kulture, ipak je u novije doba prisutno razmišljanje o mogućem datiranju pomaknuto u prvu polovinu 10. st., a moguće i ranije već tijekom 9. st. (Tomičić 1992; 2010: 123; Petrinec 2009: 234). Navedena četiri primjerka lijevanih naušnica s grozdastim ukrasom trupa i s četirima koljencima na krakovima iznimno vjerno odražavaju izgled mogućeg prototipa, tj. luksuznog izvornika koji je rađen $\mathrm{u}$ tehnici granulacije od plemenite kovine. Ta se tehnika vrlo vješto oponašala na navedenim primjercima naušnica iz Bagruše i stoga neupitno upućuje na postojanje vrlo kvalitetnih kalupa za njihovo lijevanje u srebru ili leguri srebra i bronce, pa na taj način i na relativnu blizinu nekoga važnog središta sa zlatarskom tradicijom umjetničkoobrtnog stvaralaštva. Navedene lijevane primjerke naušnica iz grobnih cjelina 11, 18 i 19 moglo bi se, sukladno Gieslerovoj tipologiji, označiti kao prototip G.17a, jer vrlo vjerno i brižno oponašaju luksuzne primjerke rađene u tehnici granulacije. Drugoj inačici lijevanih naušnica s grozdastim ukrasom i četirima koljencima pripisujemo tri brončana primjerka otkrivena u grobnoj cjelini broj 139 (Žeravica 1985-1986: T. VII, 4-6; Tomičić 2010: Tabla XXIII, 1-4). Takve je rustikalne lijevane primjerke naušnica Giesler označio kao tip G.17b razlikujući ih od luksuzne inačice rađene $u$ tehnici granulacije (tip G.17a). Rustikalne inačice izrađivali su u jednostavnim dvodijelnim kalupima, vjerojatno $u$ ranosrednjovjekovnim seoskim radionicama, putujući „zlatari“.

Kada je riječ o primjercima iz Bagruše, potpuno je jasno da pripadaju naušnicama s grozdastim ukrasom i četirima koljencima, dakle Gieslerovu tipu 17. Postojanje dviju inačica naušnica s grozdastim ukrasom i četirima koljencima, tj. prototipa Gieslerova tipa 17a i 17b, unutar grobnog inventara Bagruše, jasno potvrđuje vrlo ranu pojavu te skupine nakita na tom iznimno važnom nalazištu ranoga srednjovjekovlja. Posebice važnom držimo činjenicu da, pokraj dobre kvalitete izrade, tih, uvjetno rečeno, luksuznijih naušnica - zapravo prototipa inačice 17a, upada u oči i njihovo pojavljivanje u kombinaciji s najranijim nakitom koji inače susrećemo unutar fundusa bjelobrdske kulture. To su u grobnoj cjelini broj 11 već ranije spomenute lijevane grozdaste naušnice $s$ dvama koljencima (tip G.14), jednostavne karičice rastavljenih krajeva (tip G.13), narukvica od trostruko upletene brončane žice (tip G.6) i prstena lijevanog obruča s presjekom nalik slovu D (tip G.31), odnosno s krunom prstena (tip G.38b) i perforiranim rimskim novcem (tip T.44a). Nadalje, u grobnoj cjelini broj 18 uz prototip luksuznije inačice naušnice 17a pronađena je loše uščuvana karičica od upletene žice. Konačno, u grobnoj cjelini broj 19, pokraj prototipa luksuzne inačice naušnice 17a, na dječjoj lubanji (djevojčice) pronađena je brončana srcolika aplika staromađarskoga stilskog obilježja, a na trbuhu i okrugla pločica od brončanog lima (Tomičić 2010: 124). Svi navedeni luksuzniji prototipi inačica naušnica 17a iz 
Bagruše manjih su dimenzija $u$ odnosu na srodne primjerke s ostalih nalazišta te skupine nakita, posebice unutar riječnih tokova Mure, Drave, Dunava i Save, ali i u fundusu groblja u sjeverozapadnoj Bosni. Što se pak tiče tzv. lijevanih rustikalnih inačica naušnica $17 \mathrm{~b}$, otkrivenih u grobnoj cjelini broj 139 (Tomičić 2010: Tabla XXIII), i njih susrećemo u kombinaciji s brončanom lijevanom grozdastom naušnicom s dvama koljencima (tip G.14) i lijevanim prstenom (tip G.31) (Žeravica 1985-1986: T. VII, 4-8). Dakle, ponovno s ranim oblicima nakita primjerenih bjelobrdskomu kulturnom krugu. Iz navedenoga o naušnicama tipa $17 \mathrm{~s}$ nalazišta Bagruša nameće se realno uvjerenje kako je odreda riječ o vrlo ranim oblicima ukrasa koje, uz pridružene im skupine nakita, valja svakako pripisati početku korištenja ranosrednjovjekovnog groblja kraj Petoševaca. Mišljenja smo da primjerke prototipa naušnica inačica 17a iz grobnih cjelina 11, 18 i 19 možemo promatrati kao vrlo vješte kopije izvornika inačica luksuzno rađenih i granuliranjem ukrašenih grozdastih naušnica s četirima koljencima. Točnije, kao vrlo ranu i dosad neprepoznatu, tj. „nedostajuću kariku“ u razvoju tog inače vrlo omiljenog oblika nakita na ozemlju međuriječja Mure, Drave, Dunava i Save, kao i južnijih područja kneževine Hrvatske. Mnoštvo naušnica s četirima koljencima na prostoru dravsko-savskog međuriječja, kao i široko razvijena lepeza njihovih inačica, od skromnih rustikalnih primjeraka, zacijelo proizvoda putujućih ili lokalnih "zlatara“, do njihovih uzora, raskošnijih i luksuznih predložaka rađenih u složenoj tehnici granulacije, primjerice s groblja Zagreb - Stenjevec (Simoni 2004: 34-35, grob 106) ili ponešto skromnijih primjeraka s groblja u selu Zvonimirovu na položaju Veliko polje, (Tomičić 1997: grob 17), uvjeravaju nas u potrebu drugačijeg promišljanja njihova primarnog ishodišta. U kojoj je mjeri tada uopće moguće promatrati kao jedino njihovo ishodište područje Volinije, odnosno prostranstva sjeverno od lanca Karpata, koje je zacijelo snažno nadahnulo zlatarsko umijeće Bizanta, posebice u Kijevskoj kneževini. Utjecaj Bizanta evidentan je svakako i na područja dravskog-dunavsko-savskog međuriječja, u koje jamačno dolaze primarni umjetničkoobrtni poticaji i ideje, a možda i neposredni importi s istoka. Sličnu nam sliku pruža i bogato naslijeđe duge tradicije bizantskog umjetničkoobrtnog zlatarstva nastalog u romanskim gradovima na istočnoj obali Jadrana i prihvaćenog od neposrednog zaobalja, tj. Hrvatske kneževine, ali i njezina dubokog zaleđa na sjeveru. U činjenici da naušnice tipa G.17 susrećemo na relativno brojnim nalazištima dravsko-savskog međuriječja, i to u mnoštvu primjeraka, prepoznajemo i njihovu određenu izvornost na tom ozemlju. Ondje ih, naime, susrećemo u obje glavne inačice (tip G.17a i tip G.17b). U neusporedivo manjem, neznatnom broju primjeraka, gotovo unikatno, pojavljuje se taj tip nakita na ponekom nalazištu unutar srednjeg Podunavlja u jezgri 
onodobne susjedne staromađarske kneževine, odnosno kraljevstva. Stoga nam se kao prihvatljiviji pravci mogućega umjetničkoobrtnog utjecaja na tlo međuriječja Drave i Save, nameće istok, odnosno posebice jug, tj. zlatarska tradicija i impulsi, a ponegdje, možda, i neposredni importi iz Bizantskog Carstva i Sredozemlja. Premda je svojedobno J. Giesler zaključio kako su naušnice tipa 17 bile mlađe od ostalih tipova lijevanih naušnica (tipovi G.14, 15 i 16), na čijem se području rasprostiranja u početku pojavljuju kao import (tip G.17a), a tek naknadno kao rustikalna lijevana inačica (tip G.17b) (Giesler 1981: 101-103), dokazano je upravo na primjeru groblja Zvonimirovo - Veliko polje (Tomičić 2003: 552), ali i u slučaju groblja Zagreb - Stenjevac (Simoni 2004), da se obje te inačice pojavljuju i sinkrono. To naglašavamo zbog činjenice da i u Bagruši nailazimo na sličan primjer moguće sinkronosti obiju inačica tipa G.17. Ondje se doduše u grobnim cjelinama 11, 18 i 19 u početku pokapanja, tj. u fazi Bagruša I, susreću navedeni prototipi inačice naušnica 17a, a u grobnoj cjelini 139, dakle u fazi Bagruša III, primjerci lijevanih izrazito rustikalnih primjeraka naušnica inačice $17 \mathrm{~b}$.

Nalazi naušnica tipa 17 u Bagruši dokazuju njihovu raniju pojavu u fundusu groblja na redove $s$ kršćanskim načinom pokapanja primjerenim bjelobrdskom kulturnom krugu, od one dosad poznate, tj. od kraja 10. st. Pretpostavljamo kako im začetke u Bagruši valja tražiti možda i potkraj 9. st. Svakako na temelju još starijih izvornika (Tomičić 2010: 126).

Spomenimo u prikazu pojave rustičnih srebrnih lijevanih grozdastih naušnica s četirima koljencima (tip G.17b) i važnu činjenicu da je u groblju Zvonimirovo - Veliko polje registrirano šest grobnih cjelina sa sveukupno čak 33 primjerka te vrste nakita oglavlja (Tomičić 2012). Zanimljiva je činjenica da se u Velikom polju pokraj 29 primjeraka naušnica tipa G.17b pojavljuju i 4 primjerka kvalitetnije izvedenih srebrnih naušnica s četiri koljenca koje bismo mogli označiti kao neke vrste prijelaznu inačicu prema luksuznom granuliranom tipu G.17a. U tom su smislu posebno važne za spoznaju o dokazanoj sinkronosti spomenutih inačica grozdastih naušnica s četirima koljencima inventar grobne cjeline 17 i 19 . U spomenutim grobnim cjelinama pokopanih rodovskih odličnica pojavljuju se po dvije luksuzne naušnice s četirima koljencima inačice G.17a, usporedno s inačicama G.17b (Tomičić 2012). Posebno važnom spoznajom iz fundusa groblja Zvonimirovo - Veliko polje držimo i usporedno pojavljivanje naušnica tipa G.17 u kombinaciji s lijevanim grozdastim naušnicama tipa G.14, G.15 i G.16. To su činjenice koje uvjerljivo i temeljito ispravljaju svojedobne Gieslerove stavove u svezi s datiranjem naušnica tipa G.17a i G.17b. Dakle, naušnice tipa G.17 ne pojavljuju se kronološki nakon spomenutih bjelobrdskih primjeraka tipa G.14, G.15 i G.16 već su na temelju dokaza iz Velikog polja istodobne s njima, kao i s karičicama 
velikog obruča sa S-petljom (tip G.I), običnim karičicama (tip G.13), prstenima tipa G.31, tipa G.34 i tipa G.38a, odnosno i s pojedinačnim primjercima srcolikih privjesaka (tip G.9b, tip D.6 i D.10) ili ogrlicama od dvočlanih srcolikih privjesaka (tip D.6 i D.10, tip T.42a) (Demo 1983; Tomičić 2012). Svi navedeni primjerci ukrasa oglavlja i ogrlica mogu se pouzdano datirati u početak rane faze I. stupnja bjelobrdske kulture. To u našem slučaju konkretno znači u početke pokapanja na položaju Veliko polje kraj Zvonimirova. Zanimljiv je i podatak da se u grobnim cjelinama 9 i 40 pokraj lijevanih naušnica s četirima koljencima inačice G.17b usporedno pojavljuju i ogrlice od dvodijelnih srcolikih privjesaka tipa T.42a. O njihovoj sinkronoj pojavi bit će više riječi u nastavku prikaza grobne cjeline 40 .

Na pouzdano dokazano rano pojavljivanje grozdastih lijevanih naušnica $s$ četirima koljencima tipa G.17b upućuje jedan vrlo važan i zanimljiv nalaz brončanog primjerka, otkriven u ovalnoj jami 1712 nalazišta Velika Gorica - Šepkovčica u okolici Zagreba (Bugar 2008: 187, sl. 4:1, 40). Radiokarbonska analiza uzorka iz ranije navedene jame pokazala je da kalibrirana datacija iznosi $C^{14} 2 \Sigma$ cal. AD 1030-1157 s 95,4\% vjerojatnosti. To je svakako izuzetno važan argument u prilog pojavi grozdastih rustikalnih lijevanih naušnica s četirima koljencima (tip G.17b) u međuriječju Drave i Save. Nalaz se zbog blizine Siska opravdano može povezati s umjetničkoobrtnom radionicom u tom gradu (Bugar 2008: 192).

\section{Ogrlica od dvodijelnih srcolikih privjesaka - tip G.9a, tip D.10 i tip T.42a.}

U grobnoj cjelini 40 bila je pokopana mlađa osoba, zacijelo djevojčica, opremljena bogatom ogrlicom od perli od puhanog stakla, upotpunjenom srebrnim srcolikim dvodijelnim privjescima te brončanim praporcima. Posebice je zanimljivo otkriće i uščuvani dio trake od tekstilnih niti na kojem su u dvije isprepletene niske bile nanizane perle i privjesci. Time je jamačno rasvijetljen način na koji se takav osebujni ukras nosio. Zapravo, riječ je o prednjoj strani poruba ovratnika haljine na kojem su ukras bili srebrni srcoliki dvodijelni privjesci i dva brončana praporca. U nastavku se pozornost posvećuje vrjednovanju tog zanimljivog ukrasnog detalja. Zanimanje za genezu i podrijetlo dvodijelnih srcolikih privjesaka izrazili su J. Hampel, J. Brunšmid, Z. Váňa, G. Fehér, B. Szőke i J. Giesler, a posebice se tom ukrasnom elementu posvetio Željko Demo (Demo 1983: 275, bilj. 65-73). Njegov temeljiti prikaz bjelobrdskih dvodijelnih srcolikih privjesaka odraz je vrlo profesionalnog pristupa toj skupini nakita, pa ga u radu učestalo navodimo. Poznato je da su se takvi dvodijelni srcoliki privjesci koristili kao ukrasni porub odjeće, najčešće na vratu (Demo 1983: 271, bilj. 5 i 6) ili rijetko na prsima (Demo 1983: 271, bilj. 7). Na temelju vrlo podrobne analize te skupine ukrasa, koju je još 1983. godine proveo Demo, manje brojnu skupinu 
čine dvodijelni srcoliki privjesci koji su korišteni kao ukras ogrlice sastavljene od staklenih perli (Demo 1983: 271, bilj. 9) ili pak kao samostalni elementi ogrlice našiveni na končanu ili nešto širu tekstilnu podlogu (Demo 1983: 271, bilj. 10). Dokazano je da je ta skupina nakita najčešća u Karpatskoj kotlini, gdje je u okviru bjelobrdskog kulturnog kompleksa registrirana poglavito kao inventar u ženskim grobovima na grobljima 10. i 11. st. ili, preciznije, od druge polovice 10. i prve trećine 11. st. (Demo 1983: 271, bilj. 11, 12 i 13). Sukladno Gieslerovu uvjerenju, dvodijelni srcoliki privjesci (tip G.9) jedna su od spona između staromađarskog kulturnog kruga nalaza i bjelobrdske kulture (Giesler 1981: 90, Taf. 50, 2; Taf. 53, 1-2), koje je inače uvrstio u poglavlje posvećeno oblicima nakita koji su nastavili trajati, ali kojima izvorište valja ipak tražiti u staromađarskom miljeu (Giesler 1981: 90). Podsjetimo se da Giesler razlikuje tri skupine, odnosno: tip C staromađarskog horizonta; 9a, koju smatra staromađarskim oblikom, i 9b, koja je prenesena u registar oblika bjelobrdskog kulturnog kruga (Giesler 1981: 53, 1-2). ${ }^{3}$ Od druge polovice 10. do u treće desetljeće 11. st. trajala bi uporaba tipa G.9b, odnosno prema tipološkoj klasifikaciji dvodijelnih srcolikih privjesaka tipa D.13.

Pri vrjednovanju dvodijelnih srcolikih privjesaka za područje Jugoslavije Demo je 1983. godine posebice detaljno analizirao njihovu pojavu i u međuriječju Mure, Drave, Dunava i Save (Demo 1983: 117-166). U međuriječju je Demo, na do tada, tj. do 1983. godine, 11 poznatih nalazišta, promatrao indeks zastupljenosti pet tipoloških skupina koje su prepoznatljive na temelju stilskih obilježja. To su tipovi broj D.6, D.10, D.12, D.13 i D.16, koji su, prema rezultatima njegove analize, ujedno i najbrojnija kategorija dvodijelnih srcolikih privjesaka na području koje je proučavao (Demo 1983: 117-166).

$\mathrm{Za}$ analizu te skupine nakita $\mathrm{u}$ inventaru grobne cjeline 40 unutar groblja Zvonimirovo - Veliko polje bitan je tip D.10, tj. Gieslerov tip 9a, koji je Demo unutar međuriječja Mure, Drave, Dunava i Save registrirao na 11 nalazišta (Demo 1983: 286, sl. 10). Na temelju nalaza iz grobne cjeline 40 na položaju Velikoga polja kraj Zvonimirova sada brojimo sveukupno 12 nalazišta. Nalazi tipa D.10 registrirani su u Srijemu, Slavoniji, Podravini, Međimurju, predalpskom prostoru Slovenije, sjeverozapadnoj Bosni i Hercegovini i srednjoj Dalmaciji. Nadalje, Demo je dokazao pojavu tog oblika nakita na tri nalazišta u susjednoj Mađarskoj, a u Rumunjskoj na dva položaja groblja (Demo 1983: 286, sl. 10).

Motiv stilizirane ptičje glave (?), kako ga je nazivao J. Hampel (Demo 1983: bilj. 150), ili sovine glave, kako ga je istodobno opisivao J. Brunšmid (Demo 1983:

U Gieslerovu relativno-kronološkom smislu nešto starija bila bi inačica 9a koja se pojavljuje od rane faze I. stupnja bjelobrdske kulture, od oko 970 . godine pa do konca te faze, potkraj vremena vladavine kralja Stjepana I. Svetog (1000. - 1038.). 
bilj.151), jedan je od najčešćih i rasprostranjenijih ukrasnih elemenata donjih dijelova bjelobrdskih privjesaka.

Osvrnimo se na usporedne pojave dvodijelnih srcolikih privjesaka tipa D.10 na području susjedne Mađarske. Već je ranije Demo u njegovu skupinu tipa D.10, koju karakterizira motiv glave sove na donjem dijelu privjeska, uvrstio groblja Csongrád - Mama u Potisju (Demo 1983: 286, sl. 10) ${ }^{4}$, Fiad - Kérpuszta u Županiji Somogy, jugoistočno od Blatnog jezera ${ }^{5}$ i Vasas-Somogy u Županiji Baranja. ${ }^{6}$ Naknadnim traganjem za usporednim pojavama motiva glave sove na dvodijelnim privjescima tipa D.10 nailazi se na zanimljive analogije na nekolicini groblja $\mathrm{u}$ Potisju. U gornjem je Potisju na groblju Beregszász pronađen dvodijelni privjesak tipa D.10 s motivom glave sove. ${ }^{7}$ Nadalje, također u Potisju, na groblju Püspőkladany - Eperjesvölgy (Županija Hajdu Bihar) u grobnoj cjelini 107 pronađen je ukras oglavlja od bronce, koji se sastoji od 8 gornjih dijelova privjeska i jednog dvodijelnog privjeska s motivom sove. ${ }^{8} \mathrm{Na}$ prednjem uzvišenom dijelu okova sedla ratnika pokopanog u grobnoj cjelini 103 groblja Sárretudvari - Hítzóföld u Potisju (Županija Hajdu - Bihar) ${ }^{9}$, pronađena su 3 komada okova s motivom glave kljunaste predatorske ptice (sova) $)^{10}$. U istom je groblju pronađen i srebrni privjesak ukrasa kaftana u obliku stilizirane glave sove (?). ${ }^{11}$

Nakon provedene analize svekolikog do 1983. godine postojećeg fundusa dvodijelnih srcolikih privjesaka Demo je iznio mišljenje da „,... su privjesci tipa 10 kao i importirani tip 12 pristigli u područje alpskih Slavena i dalmatinskih Hrvata iz jugoistočnih panonskih prostora pri čemu pomišljamo na prostor omeđen Dravom, Savom i Dunavom" (Demo 1983: 293). Inače, Demo je na temelju reduciranog indeksa privjeske tipa D.10 svrstao u kategoriju importiranih motiva, iako je izrazio i, po našem uvjerenju opravdanu, rezervu da se za tu soluciju mogao teško odlučiti (Demo 1983: 292). U doba nastanka rasprave o

4 Váňa, Zdenek,1954.Mad'aři a Slované ve světle archeologických nálezú X-XII. stoleti, SIA II, Bratislava, 51- 104.(80); Fehér, Geza - Éry, K. - Kralovánszky, A, 1962, A Közép-Duna-medence magyar honfoglalás-és kora Árpád - kori sírleletei (The burials of the Conquest period and the early Arpadian Age in the Middle Danube Basin). Régészeti Tanulmányok 2, Budapest, 29, Nr. 188;

5 Fehér 1962, 36 Nr. 318.

6 Fehér 1962, 61 Nr. 813.

7 THE ANCIENT HUNGARIANS Exhibition Catalogue, Ed. István Fodor, Budapest, 1996, 133.

8 The Ancient Hungarians, 1996, 245, 250, Fig. 16.

9 The Ancient Hungarians, 1996, 245, 263-264, Fig. 16.

10 The Ancient Hungarians, 1996, 263, Fig. 16; Nepper, M, I, 1993. Neuere Gräberfelder aus der Landnahmezeit aus Hajdú-Bihar Komitat, DMÉ, 79-107, (99).

11 The Ancient Hungarians, 1996, 276, Fig. 47; Nepper, M. I. - Révész, L. 1990, Etelközből a Kárpát-medencébe. A honfoglalók legújabb leletei (Aus dem Etelköz ins Karpatenbecken. Die neueste Funde aus der Landnahmezeit) Exhibition Catalogue, Debrecen,1990, 19-29. 
dvodijelnim privjescima Demo je bio uvjeren u činjenicu da su njegove tipološke skupine 6 i 16 bile, najvjerojatnije, južnopanonski radionički proizvod u čijem su oblikovanju mogle sudjelovati i sisačke radionice ranosrednjovjekovnog nakita (Vinski 1970; Demo 1983: 292, bilj. 191). Dvodijelni srcoliki privjesci $\mathrm{s}$ ukrasom glave sove na donjem privjesku, pronađeni $\mathrm{u}$ grobnoj cjelini $40 \mathrm{u}$ groblju Zvonimirovo - Veliko polje, dokazuju moguću autohtonost tipa D.10 na prostoru međuriječja Mure, Drave, Dunava i Save. Međutim, pritom svakako treba pri budućim raspravljanjima privjesaka tipa D.10 uzeti u obzir i ranije nabrojene srodne primjerke pronađene na području mađarskog dijela Potisja, Baranje i jugoistočno od Blatnog jezera. Općenito, treba svakako razmotriti genezu i simboliku motiva glave sove na dvodijelnim privjescima. Odakle je došao taj umjetnički poticaj? Je li u njegovoj pozadini možda oznaka, tj. amblem nekog staromađarskog plemena, odnosno rodovske zajednice, ili je simbolika rezultanta mitoloških vjerovanja još iz poganskog razdoblja, iz dalekih azijskih ishodišta doseljavanja Ugra? U duhovnom smislu sove su svakako predmet mitsko-religijskog svijeta (Skok 2014: 67). Dakle, je li možda riječ o određenom slikanju života i stvarnosti, iako je njena tematika bestijarija ograničena najčešće na prostorno i vremenski veoma udaljena ili sasvim nerealna zbivanja (LEKSIKON 2006: 2425)? Kontinuitet povijesti vizualnih medija i značenje tradicije unutar primjerice umjetničkog obrta (,zlatarstva“), gdje je zajedno s tehnikom rada majstor nužno prenosio učeniku i određenu ikonografiju i oblikovna rješenja, najočitije se iskazuje u primjerima preuzimanja, u svijesti duboko ukorijenjenih poganskih simbola (LEKSIKON 2006: 26). Stoga valja pokušati proniknuti u simboliku sove, koja pripada rodu noćnih ptica grabljivica (Striges, Strigiformes). Simbol su mudrosti, tuge, sjetne i samotnjačke povučenosti zbog toga što se ne izlažu dnevnoj svjetlosti. U grčkoj mitologiji sova prikazuje Atropu, onu od Parki koja pretrgne nit života. Sova se može smatrati glasnikom smrti, pa prema tome i zlokobnom. Kao Atenina ptica, simbolizira misao što vlada tminama (RJEČNIK SIMBOLA 1987: 619-620; LEKSIKON 2006: 573 / Sova). U povoljnom smislu sova je oznaka Krista koji se žrtvovao da spasi svijet, „,... da obasja one koji prebivaju u tami i sjeni smrtnoj..." (Lk 1,79). To tumači njezinu nazočnost na prizorima raspeća (LEKSIKON 2006: 573 - Marijan Grgić).

Ranije je na primjeru grobne cjeline 5 u groblju Csongrád - Máma u Potisju (Váňa 1954, 80; Fehér 1962: 29 Nr. 188), u kojoj su kao grobni nalazi otkrivena četiri primjerka dvodijelnih privjesaka tipa D.10 i srebrni denar prvog ugarskog kralja Stjepana I. Svetog (1000 - 1037.), Demo iznio prihvatljiv prijedlog datiranja spomenutog tipa privjesaka u prvo desetljeće 11. st. (Demo 1983: 286). 


\section{Šuplji praporci - tip G.10a}

Zanimljiv su detalj na opisanoj ogrlici od dvodijelnih srcolikih privjesaka dva brončana šuplja praporca koja su, prema Gieslerovoj tipologiji, označena kao tip G.10a. Posebice je važan nalaz praporca na čijoj se ušici nalaze ostaci tkanine na koju je praporac bio pričvršćen. To je važan detalj koji dokazuje da su praporci bili sastavnim dijelom ogrlice. Praporci su na području međuriječja dokazani na 17 nalazišta, a ujedno i na 4 nalazišta u sjeverozapadnoj Bosni i Hercegovini. Na uništenom groblju kraj Kloštra Podravskog nađena je ogrlica u kojoj se praporci i dvodijelni srcoliki privjesci dopunjuju. Inače se takve ogrlice od praporaca, tj. tip T.42b, dokazano pojavljuju tijekom rane faze I. stupnja bjelobrdske kulture, a nakon toga iščezavaju kao zaseban oblik nakita na području međuriječja Mure, Drave, Dunava i Save (Tomičić 1989: 487-488, T. 196). Dakle, i šuplje brončane praporce iz grobne cjeline $40 \mathrm{u}$ groblju na Velikom polju kraj sela Zvonimirova možemo svrstati u ranu fazu I. stupnja bjelobrdske kulture.

\section{Ostaci tkanine}

U zaključnom osvrtu na pokojnicu pokopanu u grobnoj cjelini 40 ne treba zaboraviti ni njezin sociološki status unutar rodovske zajednice koja je svoje pripadnike pokapala na položaju Veliko polje u relativnoj blizini ranosrednjovjekovnog sela. Pokojnica, tj. djevojčica, sukladno općoj pojavi prisutnoj u duhovnom svijetu bjelobrdskog kulturnog kruga bila je raskošno opremljena prije polaganja u plitku grobnu raku u blizini preostalih istaknutijih članova rodovske zajednice. Djevojčica je okićena nakitom oglavlja od šest srebrnih grozdastih lijevanih rustičnih naušnica s četirima koljencima (tip G.17b) nanizanih vjerojatno na lanenu vrpcu i upletenih u kosu pokojnice. Njezina je, vrlo vjerojatno, lanena haljina bila ukrašena atraktivnom ogrlicom, zapravo porubom ovratnika odjeće, od osam srebrnih dvodijelnih srcolikih privjesaka (tip D.10; tip T.42a), dva brončana šuplja praporca (tip G.10) i raznobojnih perli od puhanog stakla, našivenom na djelomično uščuvanu tekstilnu traku.

Otkriveni djelići tekstila bacaju posebno svjetlo na status pokojnice ukopane u grobnu raku 40. Riječ je o izuzetno rijetkim organskim arheološkim nalazima koji su uslijed klimatskih i pedoloških uvjeta unutar Karpatske kotline općenito registrirani $\mathrm{u}$ malom postotku. Pionir sustavnog istraživanja važnosti nalaza tekstila u grobljima 10. - 11. st. srednjeg Podunavlja jest Chanád Bálint, koji je prvi skrenuo pažnju arheologa na male fragmente odjeće pokopane s pokojnikom, kao i na njihov odnos prema kovinskim predmetima u naslijeđu 10. st. ${ }^{12}$

\footnotetext{
Bálint, Csánad 1971. X. századi temető a szabadkígyósi-pálligeti táblában (Tenth century cemetery in the Pálliget plot of Szabadkígyós). BMMK 1 (1971) 40-88, (73).
} 
Bálintove pretpostavke, utemeljene na primjeru groba 12 s groblja Szabadkígyós - Pálliget u Potisju, rezultirale su spoznajama da su rijetki i malobrojni nalazi tekstila zapravo dokazivali bogatstvo te financijsku i komercijalnu pozadinu obitelji pokopanih u grobljima 10. st. (Bálint 1971, 73; Bollók et alii. 2009, 147). Većina fragmenata tekstila registrirana je na grobljima 10. - 11. st. u Potisju (Bollók et alii. 2009, 152, fig. 6). Neki od njih sastojali su se od niti, tj. konaca, a neki od struktura. Većina vlakana bila je od lana, ali bilo je ponekih i od svile, primjerice iz groba 1 u groblju Jánosszállás - Katonapart (Bollók et alii. 2009, 152, n. 65). Ujedno je većina vlakana nađena kao učvršćenje kovinskih ukrasa, što je bilo uobičajeno pri ukrašavanju ovratnika odjeće, pretpostavljeno košulja. Naime, vlakno je držalo kukice ovješene kroz proreze u strukturi tekstila, uglavnom u serijama, tako da jedno tkivo drži razne kukice.

Materijali i tehnike tkanja tekstilnih struktura mogu biti podijeljene u dvije skupine. Prva čine tkanja od svile, a druga od lana (Bollók et alii. 2009, 152). U Karpatskoj kotlini, većinom istočno od Dunava, svilene su strukture otkrivene u 14 grobnih cjelina u grobljima 10. - 11. st. Ondje čine 35\% svih tekstilnih ostataka. Osim materijalnih potvrda nalaza tkanina za skupocjenu odjeću starih Mađara, svjedoče i ranosrednjovjekovna pisana vrela (Ibn Rusta, Gardïzï i Masüdï) koja dokazuju trgovačke, ali i vojne kontakte između Ugara i Bizanta i ostalih regija (Bollók et alii. 2009, 148, n. 7-11).

\section{Zaključna razmatranja}

Pri polaganju u grobnu raku pokojnica je umotana u platno položena glavom na zapadnoj strani. Dakle, s pogledom prema Istoku, tj. izlasku Sunca. Zbog plitkog ukopavanja, što je opća pojava unutar groblja bjelobrdskog kulturnog kruga, a posebice kada je riječ o djeci, vrlo je često oštećivanje kostura. To je slučaj i u grobnoj cjelini 40, u kojoj su ralom pluga tijekom brojnih preoravanja Velikog polja oštećena lubanja, ali i dijelovi tijela djevojčice. Ipak, unatoč oštećenjima kostura, uspjelo se in situ otkriti položaj pokretnih grobnih nalaza, tj. ukrasa oglavlja i odjeće pokojnice. Ti ukrasi pokojnicu, tj. djevojčicu iz grobne cjeline 40, jasno uvrštavaju unutar šire slike groblja kraj sela Zvonimirovo u kojem je možemo pouzdano smjestiti u skupinu pokojnika koje promatramo, zbog njihova grobnog inventara, kao pripadnike imućnijeg dijela seoske rodovske zajednice. Zacijelo je riječ o rodovskim odličnicima, tj. istaknutom sloju ruralne zajednice koja je okrenuta poljodjelstvu bila naseljena u obližnjem selu, smještenom neposredno uz prastaru prometnicu. Ta je prometnica iz podravskog dijela međuriječja riječnim prijelazom preko Drave bila neposredno povezana s prostorom susjednog Ugarskog Kraljevstva. Na taj je način populacija ranosrednjovjekov- 
nog sela bila uključena u trgovačke kontakte, razmjenu dobara te na mogućnosti pribavljanja raznolikih primjeraka ukrasa oblikovanih u regionalnim ili bližim umjetničkoobrtnim središtima. S obzirom na velik broj od 33 primjerka srebrnih grozdastih naušnica s četirima koljencima otkrivenih u groblju Zvonimirovo Veliko polje, može se pomišljati i na njihovu lokalnu proizvodnju ili povremeni boravak putujućih „zlatara“. To dokazuju brojni tipovi i inačice ukrasa oglavlja, odjeće i ruku koji kao grobni nalazi u obližnjem groblju na Velikom polju zrcale sliku o visokoj razini tamošnje imućne rodovske zajednice.

Ruralna je zajednica svoje pokojnike pokapala u groblju na Velikom polju tijekom barem dva do tri uzastopna naraštaja, tj. u intervalima 25 - 30 godina, od prvih desetljeća 10. do konca 11. st. Ta činjenica dozvoljava realnu pretpostavku da se život ruralne rodovske zajednice odvijao svakako tijekom 10. st., a vrlo vjerojatno i ranije.

Naposljetku, primjerci ukrasa oglavlja i ogrlice obruba odjeće pokojnice otkriveni u grobnoj cjelini 40 mogu se pouzdano datirati u početak rane faze I. stupnja bjelobrdske kulture. To u našem slučaju konkretno znači u početke pokopavanja na položaju Veliko polje kraj sela Zvonimirova. Ta je faza pokopavanja nazvana Zvonimirovo I. Pokušamo li dati naznake tipološko-kronološkog okvira inventara otkrivenog u grobnoj cjelini 40, tada je riječ o razdoblju vladavine hrvatskih kraljeva Mihajla Krešimira II. (969.), Stjepana Držislava (997.) i Mihajla Krešimira III. (1000. - 1030.), mađarskih kneževa Taksonya (972.) i Geze (997.) te njihova prvoga kralja Stjepana I. Svetog (997. - 1030.). Ujedno taj okvir određuju bizantski carevi Roman II., Nikifor i Ivan Cimisk (969. - 976.), Bazilije II. (976. - 1025.) i carevi Svetoga rimskog Carstva od Otona I. Velikog (962. - 973.) do Konrada II. (1027. - 1039.). 


\section{LITERATURA / BIBLIOGRAPHY}

Bálint, Csánad 1971., X. századi temető a szabadkígyósi-pálligeti táblában (Tenth century cemetery in the Pálliget plot of Szabadkígyós). BMMK 1 (1971) 40-88, (73).

Bollók, Á.- Knotik, T.- Langó, P.- Nagy, K. E. - Türk, A. A., TEXTILE REMNANTS IN THE ARCHAEOLOGICAL HERITAGE OF THE CARPATHIAN BASIN FROM THE 10th-11th CENTURIES, Acta Archaeologica Academiae Scientiarum Hung. 60 (2009), In honorem Csanád Bálint, Académiai Kiadó, Budapest, 2009, 147-221.

Brunšmid, J. 1903/1904, Hrvatske sredovječne starine, VHAD n. s. 7, Zagreb, 30-97.

Bugar, A. 2008, Naselje ranog srednjeg vijeka Velika Gorica - Šepkovčica. Zbornik radova „Srednji vek - Arheološke raziskave med Jadranskim morjem in Panonsko nižino" (Srednji vijek - Arheološka istraživanja između Jadranskog mora i Panonske nizine), Urednik Mitja Guštin, Ljubljana - Zagreb, 179-196.

Demo, Ž. 1983, Bjelobrdski privjesci u Jugoslaviji, Podravski zbornik '83, 271-301.

Dizdar, M. 2005, Groblje latenske kulture u Zvonimirovu - prilog poznavanju pogrebnih običaja i vjerovanja Tauriska u Podravini, Histria Antiqua 13, Pula, 85-98.

Dizdar, M. 2013, Zvonimirovo Veliko polje. Groblje latenske kulture (A Cemetery of the La Tène Culture) 1, Monografije Instituta za arheologiju 8, Zagreb.

Fehér, G. - Éry, K. - Kralovánszky, A, 1962, A Közép-Duna-medence magyar honfoglalás-éskora Árpád - kori sírleletei [The burials of the Conquest period and the early Arpadian Age in the Middle Danube Basin]. Régészeti Tanulmányok 2, Budapest.

Giesler, J. 1981, Untersuchungen zur Chronologie der Bijelo Brdo - Kultur. Ein Beitrag zur Archäologie des 10. und 11. Jahrhunderts im Karpatenbecken, Prähistorische Zeitschrift 56, 1, Berlin, 4-167.

Green, Kevin. ARCHAEOLOGY An Intraduction, 1995.

Hampel, J. 1905, Alterthümer des frühen Mittelalter in Ungarn, 1-3, Braunschweig, 759 i d., 819 i d. LEKSIKON = Leksikon ikonografije, liturgike i simbolike zapadnog kršćanstva, Zagreb, 2006.

Nepper, M, I. 1993, Neuere Gräberfelder aus der Landnahmezeit aus Hajdú-Bihar Komitat, DMÉ, 79-107.

Nepper, M. I. - Révész, L. 1990, Etelközből a Kárpát-medencébe. A honfoglalók legújabb

leletei [Aus dem Etelköz ins Karpatenbecken. Die neueste Funde aus der Landnahmezeit] Exhibition Catalogue, Debrecen: 19-29.

Petrinec, M. 2009, Groblja od 8. do 11. stoljeća na području ranosrednjovjekovne hrvatske države, Monumenta medii aevi Croatiae 3, Split.

RJEČNIK SIMBOLA 1987, Chevalier, J. - Gheerbrant, A., Zagreb. 1987.

Sekelj Ivančan T. - Belaj J. 1998, Probno sondažno iskopavanje u selu Zvonimirovu godine 1998., Obavijesti HAD-a XXX/3, Zagreb, 112-117. 
Simoni, K. 2004, Stenjevec - starohrvatsko groblje, Katalog izložbe, Zagreb.

Skok, Z. 2014, Hrvatski dijalektni frazemi s leksemom životinje kao sastavnicom, KAJ, XLVII, Zagreb 5-6, 67-82.

Sokol, V. 2006, Hrvatska srednjovjekovna arheološka baština od Jadrana do Save, Zagreb.

Szőke, B. 1962, A honfoglaló és kora Árpád-kori magyarság régészeti emlékei [The archaeological heritage of the Coquest period and the Early Arpadian Age]. Régészeti Tanulmányok I, Budapest.

THE ANCIENT HUNGARIANS Exhibition Catalogue, Ed. István Fodor, Budapest, 1996.

Tomičić, Ž. 1989, Arheološka slika međuriječja Mure, Drave, Dunava i Save u svjetlosti materijalnih izvora bjelobrdskog kulturnog kompleksa, doktorska disertacija, Filozofski fakultet, Zagreb.

Tomičić Ž. 1994, Istraživanja srednjovjekovnoga groblja Zvonimirovo-Veliko polje u Virovitičko-podravskoj županiji, Obavijesti HAD-a XXVI/2, Zagreb, 61-64.

Tomičić Ž. 1997, Zvonimirovo i Josipovo groblja starohrvatskoga doba u Virovitičkopodravskoj županiji, Zagreb -Virovitica.

Tomičić Ž. 1999, Ranosrednjovjekovno groblje Zvonimirovo-Veliko polje. Prinos poznavanju bjelobrdske kulture u podravskom dijelu Slavonije, Prilozi Instituta za arheologiju vol. 13-14 (1996.1997.), Zagreb, 91-120.

Tomičić Ž. 2004, Rezultati istraživanja na Velikom polju kraj sela Zvonimirova tijekom godine 2004., Obavijesti - Hrvatsko arheološko društvo XXXVI/3, Zagreb, 122-126.

Tomičić Ž.- Dizdar M. 2005, Grobovi latenske kulture s Velikog polja u Zvonimirovu - rezultati istraživanja 1993.-1995., Prilozi Instituta za arheologiju u Zagrebu 22, Zagreb, 59-125.

Tomičić, Ž. 2010, Spoznaje o arheološkom naslijeđu ranosrednjovjekovnog groblja na položaju Bagruša kraj Petoševaca, Archaeologia Adriatica 4, Zadar, 117-166.

Tomičić, Ž. 2012, ZVONIMIROVO Veliko polje. Groblje bjelobrdske kulture, Kata$\log$, Zagreb.

Váňa, Z.1954, Mad'aři a Slované ve světle archeologických nálezú X-XII. stoleti, SIA II, Bratislava, 51- 104.

Vinski, Z. 1970, O postojanju radionica nakita starohrvatskog doba u Sisku, VAMZ III. s. 4, Zagreb, 45-92.

Žeravica, Z. 1986, Ranoslovenska nekropola Bagruša u Petoševcima kod Laktaša, GZMS n. s. XL/XLI (1985/1986), Sarajevo, 124-196. 


\section{POPIS ILUSTRACIJA}

Karta 1. Položaj groblja Zvonimirovo - Veliko polje (mj. 1 : 25.000)

Karta 2. Situacijski plan ranosrednjovjekovnog groblja Zvonimirovo - Veliko polje s položajem grobne cjeline 40. (crtež Kristina Turkalj)

Sl. 1. Zvonimirovo - Veliko polje. Grobna cjelina 40. (snimio Hrvoje Jambrek)

S1. 2. Zvonimirovo - Veliko polje. Grobna cjelina 40. (crtež Daria Ložnjak Dizdar, digitalizacija Kristina Jelinčić Vučković)

Sl. 3.,Zvonimirovo - Veliko polje. Nalazi dvodijelnih srcolikih privjesaka. Stanje tijekom istraživanja. (snimio Marko Dizdar)

S1. 4. Zvonimirovo - Veliko polje. Ogrlica od dvodijelnih srcolikih privjesaka, praporaca, puhanog staklo i tkanine. Stanje nakon istraživanja. (snimila Daria Ložnjak Dizdar)

Sl. 5 Zvonimirovo - Veliko polje. Grobna cjelina 40. Šest srebrnih lijevanih grozdastih naušnica sa četirima koljencima. Stanje prije konzerviranja. (snimio Jurica Škudar)

Sl. 6. Zvonimirovo - Veliko polje. Grobna cjelina 40. Šest srebrnih lijevanih grozdastih naušnica sa četirima koljencima. Stanje nakon konzerviranja. (snimio Hrvoje Jambrek)

Sl. 7. Zvonimirovo - Veliko polje. Grobna cjelina 40. Ogrlica od dvodijelnih srcolikih privjesaka, praporaca i staklenih perla. Stanje nakon konzerviranja. (snimio Jurica Škudar) 


\section{Summary}

\section{Grave Entity 40 from the Early Medieval Cemetery Zvonimirovo-Veliko polje}

The paper focuses on the importance of the grave entity 40 discovered in 2004 within the early medieval graveyard of the Bijelo Brdo culture in the Veliko polje area near Zvonimirovo village in Suhopolje municipality. By analyzing the grave inventory, the author tries to recognize the time frame of deceased's burial - the girl, dressed in rich ornaments of garland garments. On the basis of related comparative findings in the interspace between rivers Mura, Drava, Danube and Sava and in the neighboring part of the Carpathian Basin, the sociological characteristics of the deceased, i.e the status within the tribal community and its artistic and craftmanship and cultural affiliations are being identified. The massive inventory is a very important card in the complex and distinctive mosaic of the Bjelo Brdo cultural circle.

The rural community buried their deceased in a cemetery on the Veliko polje (Great Field) for at least two to three consecutive generations, i.e at intervals of 25-30 years, from the first decades of the 10th to the end of the 11th century. This fact allows a realistic assumption that the life of rural community took place during the course of the 10th century and probably earlier.

Finally, specimens of embellishment of the headgear and hatchlings of the deceased garments discovered in the gravestone 40 can be reliably dated to the beginning of the early Phase I stage of the Bjelo Brdo culture. This in our case specifically means the beginning of the burial in the Veliko polje area near Zvonimirova village. Here we call the phase of burial called Zvonimirovo I.

We are traying to give indications of the typological-chronological framework of the inventory discovered in the grave entity 40 then the period of the reign of Croatian kings Mihajlo Krešimir II (969), Stjepan Držislav (997) and Mihajla Krešimir III (1000-1030), the Hungarian duks Taksony (972) and Geza (997), and their first King Stjepan I the Saint (997-1030). At the same time this framework is determined by the Byzantine Emperors Roman II, Nikifor and John Cimisk (969-976), Basil II. (976-1025) and the emperors of the Holy Roman Empire from Oton I Great (962-973) to Konrad II. (1027th to 1039th).

Keywords: Zvonimirovo-Veliko polje cemetery; jewelery of headgear; decoration of clothes; birthplace; burial in rows; early Middle Ages; Bjelo Brdo Cultural Circle; Croatia. 